MAGDALENA ŻURKO

Instytut Psychologii, Uniwersytet Wrocławski Institute of Psychology, University of Wrocław magdalena.zurko@uwr.edu.pl

\title{
Przyjaźń zapośredniczona przez internet. Nowe zjawiska w rozwoju społecznym nastolatków i młodych dorosłych
}

\author{
Friendship Mediated by the Internet. \\ New Phenomena in the Social Development \\ of Teenagers and Young Adults
}

\begin{abstract}
Researchers into the impact of web-mediated communication on the quality of close friendship present two views: some provide results indicating positive effect (immediate beginning of a friendship, deepening relationships), while the others point to the risk of trivializing the human relationship. The correlation was investigated between the frequency of online contacts and the perceived quality of friendship in three age groups: late adolescents, emerging adults and young adults (643 subjects in total), as well as the moderating influence of the attitude towards the Internet (open / overwhelmed attitude). The research was carried out with the use of questionnaires Quality of Friendship (KJP) by Magdalena Żurko and Internet Interpersonal Relations (KIRI) by Dorota Chmielewska-Łuczak. A positive relationship occurred in the group of adolescents and the group of emerging adults. The attitude towards the Internet tuned out not to play a moderating role in the tested relationships in any of the age groups.
\end{abstract}

Keywords: friendship, adolescence, emerging adulthood, early adulthood, instant messengers.

Słowa kluczowe: przyjaźń, dorastanie, wkraczanie w dorosłość, wczesna dorosłość, komunikatory internetowe.

\section{WPROWADZENIE}

Szybkiemu rozpowszechnieniu współczesnych technologii komunikacyjnych towarzyszyła od ich początków dyskusja na temat wpływu masowego korzystania z nowoczesnych rozwiązań na psychospołeczne funkcjonowanie ich użytkowników. W ramach tej dyskusji ścierały się dwa sprzeczne poglądy na temat konsekwencji korzystania z komputerowo zapośredniczonej komunikacji. Wedle jednego $\mathrm{z}$ nich relacje online spostrzegane były jako płytkie i bezosobowe, a w dalszej perspektywie miały prowadzić do poczucia osamotnienia i pogorszenia samopoczucia (przegląd literatury: Kraut i in., 1998; Parks, Floyd, 1996). Zwolennicy drugiego poglądu twierdzili natomiast, że komunikacja internetowa daje nowe, większe możliwości w zakresie tworzenia i podtrzymywania relacji, powodując równocześnie ich pogłębienie $(\mathrm{Ba}-$ torski, 2004; Krejtz, Zając, 2007; Rheingold, 1993; Sheer, 2011; Wang, Wellman, 2010). Powyższe poglądy wywieść można z ogólniejszych koncepcji socjologicznych, akcentujących związki między rozwojem nowoczesnej technologii, czy szerzej: cywilizacji, a struktura społeczną i społecznym funkcjonowaniem ludzi. Można tu wymienić koncepcje: społeczeństwa 
sieciowego Manuela Castellsa (2007) czy społeczno-medialnej sieci Jana van Dijka (2010). Przestrzenią, w której realizuje się model społeczeństwa sieciowego, jest internet. Spodziewano się, że jego używanie będzie akcelerować proces usieciowienia struktury społecznej, a w konsekwencji wpłynie na jakość relacji społecznych oraz funkcjonowanie psychiczne użytkowników. $\mathrm{W}$ dalszym ciagu otwarte pozostaje pytanie o to, czy konsekwencje korzystania z internetu wiążą się bardziej ze zjawiskami negatywnymi w tym obszarze czy też wręcz przeciwnie. Kwestia ta jest znacząca zwłaszcza w kontekście rozwoju w czasie dorastania i wkraczania w dorosłość. Jednym z głównych zadań rozwojowych w tym okresie życia jest budowa trwałych, bliskich relacji, wykraczających poza związki rodzinne (przyjaźnie, związki romantyczne). Wobec tego pytanie o konsekwencje używania zapośredniczonej, sieciowej komunikacji oraz częstego przebywania w przestrzeni internetu dla jakości bliskich relacji zdaje się ważne.

\section{ROZWOJOWE ZNACZENIE PRZYJAŹNI W OKRESIE DORASTANIA I WKRACZANIA W DOROSŁOŚĆ. JAKOŚĆ PRZYJAŹNI}

Przyjaźń to jedna z relacji intymnych, która uznawana jest za istotne źródło wsparcia w ciągu całego życia. Okres dorastania - z uwagi na tempo i kryzysowy charakter zmian - to czas, w którym relacje przyjacielskie odgrywają szczególną rolę. Posiadanie przyjaciela zmniejsza lęk przeżywany w sytuacjach, w których nastolatek jest nowicjuszem, wzmacnia jego pewność siebie oraz podnosi ogólny dobrostan (Rabaglietti, Ciaviano, 2008). Jest pomocna w kształtowaniu szerokiego spektrum kompetencji społecznych oraz emocjonalnych (Buhrmester, 1990; Gauze i in., 1996). Willard W. Hartup, należący do najbardziej znanych badaczy relacji rówieśniczych $\mathrm{w}$ dzieciństwie i dorastaniu, uważa, że przyjaźń w okresie adolescencji stanowi jeden z najważniejszych kontekstów rozwoju młodzieży (Hartup, 1993). W okresie wkraczania w dorosłość znaczenie przyjaźni dla przystosowania jest także znaczące
(Bagwell i in., 2005). Ilość czasu spędzanego $\mathrm{z}$ przyjaciółmi jest mniejsza niż $\mathrm{w}$ adolescencji, jednak relatywnie jest wysoka, a charakterystyki takie jak lojalność, ciepło i podzielanie doświadczeń są tak samo ważne jak w okresie dorastania (Tanner, Arnett, 2011). Osoby wkraczające $\mathrm{w}$ dorosłość wyrażają przekonanie, że przyjaźń przewyższa relacje z rodzeństwem pod względem bliskości, wzajemności, poziomu pozytywnych uczuć i ważności (Pulakos, 2001), co jest wyrazem szerszej tendencji polegającej na zmniejszaniu się znaczenia relacji rodzinnych. Spostrzegane znaczenie przyjaźni zależy od struktury sieci związków, szczególnie od posiadania romantycznego partnera lub współmałżonka. Osoby w związkach małżeńskich wskazują współmałżonka jako osobę, która jest najbardziej godna zaufania i z która najchętniej spędzają czas. Natomiast dla osób samotnych rolę taką spełnia przyjaciel (Carbery, Buhrmester, 1998). W okresie wkraczania w dorosłość przyjaźń może osiaggać szczyt znaczenia funkcjonalnego (Tanner, Arnett, 2011).

W badaniach nad przyjaźnią najczęściej przyjmowane jest podejście relacyjne, w którym traktowana jest ona jako rodzaj relacji interpersonalnej o specyficznych charakterystykach (cechach) (Bukowski, Hoza, Boivin, 1994; Furman, 2001; Hinde, 1996). Obecność zakładanych cech w związku przesądza o jego jakości, przy czym badacze posługują się różnymi ich zestawami. Najczęściej wymieniane są: dobrowolność, wzajemność, sympatia i bliskość (Furman, 1996; Rubin, Bukowski, Parker, 1998), a także: wspólne spędzanie czasu, wsparcie i ekskluzywność (Bukowski, Motzoi, Meyer, 2009; Yu Rueger, Malecki, Demaray, 2008). Cechy te charakteryzują przyjaźń już od wczesnego dzieciństwa (Dunn, 2008). Natomiast bardziej intymne przyjaźnie nastolatków i młodych dorosłych cechują także lojalność i trwałość (Lozano, Hojjat, Sims-Knight, 2016; Mendelson, Aboud, 1999). Cechy te wynikają z tego, że przyjaźnie osób dorosłych są częściej zobowiązane (zob. teoria Roberta Sternberga za: Wojciszke, 1998). Wymienione korzyści rozwojowe związane są z przyjaźnią wysokiej jakości. Możliwe są także negatywne skutki tej relacji. Zagadnienie to jest przedmiotem badań z zakresu wpływu 
rówieśniczego, w tym przyjacielskiego (Heilbron, Prinstein, 2008; Urberg i in., 2003).

$\mathrm{Z}$ uwagi na zmiany rozwojowe dotyczące związków przyjacielskich w okresie dorastania i wczesnej dorosłości w prezentowanym badaniu przyjęto, że wysokiej jakości przyjaźń charakteryzują:

- lubienie się i wsparcie jako cechy występujące od dzieciństwa,

- bliskość (otwartość, szczerość, zrozumienie) jako cecha pogłębiająca się w okresie dorastania,

- stabilność przejawiająca się poczuciem pewności związku (lojalność, zaufanie) oraz wzajemnym zobowiązaniem jako cecha pojawiająca się od okresu dorastania (Bee, Boyd, 2008; Dunn, 2008).

Wymienione charakterystyki dotyczą spostrzegania jakości przyjaźni, a więc subiektywnego przekonania o występowaniu powyższych cech w związku. Jakość przyjaźni może być także mierzona obiektywnymi wskaźnikami, np. obiektywnym kryterium stabilności jest trwałość przyjaźni w czasie.

\section{BLISKIE RELACJE RÓWIEŚNICZE ZAPOŚREDNICZONE PRZEZ INTERNET: PRZEGLĄD BADAŃ}

Zmiany jakości usług internetowych (szybkość, multimedialność, bezpieczeństwo) oraz pojawienie się kolejnych: komunikatorów oraz serwisów społecznościowych, stworzyły nowe warunki dla społecznego funkcjonowania (Barani, 2009). W związku z tym wiele opinii formułowanych na temat specyfiki relacji zapośredniczonych przez internet u początków jego rozwoju oraz możliwych konsekwencji dla społecznego funkcjonowania użytkowników przestało być aktualne. Badania młodych użytkowników serwisów społecznościowych pokazują, że komunikują się oni online najczęściej z tymi samymi osobami, z którymi spotykają się „twarzą w twarz”, chociaż nie są to środowiska lustrzane (Subrahmanyam i in., 2008). Na podstawie wyników serii badań podłużnych ustalono także, że istnieje ciągłość pomiędzy wzorami komunikacji i jakością przyjaźni w relacjach „twarzą w twarz” a relacjami online na serwisach społecznościowych z bliskimi przyjaciółmi (Mikami i in., 2010). To podobieństwo może być wynikiem tego, że serwisy społecznościowe nie są anonimowe, w odróżnieniu od gier online, forów czy wpisów na YouTube. Ponieważ więcej osób czyta wpis, może to motywować do większej refleksyjności (Szwedo, Mikami, Allen, 2012). Wcześniejsze badania - prowadzone przed powstaniem serwisów społecznościowych - wykazywały, że interakcje internetowe były powierzchowne i występowały głównie wśród niedostosowanej młodzieży (Bargh, McKenna, 2004). Dostarczono także licznych dowodów pozytywnych związków między komunikacją online a jakością społecznych więzi nastolatków oraz ich dobrym samopoczuciem (omówienie badań: Valkenburg, Peter, 2009), jednak pod warunkiem że kontakty online z przyjacielem pokrywają się z kontaktami „twarzą w twarz”. Ten pozytywny efekt próbuje się wyjaśnić moderującym wpływem otwartości, której sprzyja komunikacja internetowa. Większa skłonność do samoujawnienia w kontaktach zapośredniczonych zwiększa intymność związku, a przez to poprawia samopoczucie. Kontakty online z przyjacielem dają także większe możliwości otrzymywania i udzielania przyjacielskiego wsparcia (Valkenburg, Peter, 2009). Z badań nad związkami między posługiwaniem się komunikatorami internetowymi a rozwojem przyjaźni nastolatków wynika, że używanie nowoczesnych mediów komunikacyjnych skraca czas potrzebny na przekształcenie nieznajomego w znajomego, ułatwia autoprezentację i poszerza grono znajomych. Natomiast pogłębienie związku i przekształcenie go w bliższą przyjaźń wiąże się tylko z używaniem wiadomości tekstowych, a inne aplikacje (wymiana linków, webcam, animacje, ikony, avatary) nie maja znaczenia (Sheer, 2011).

Nie brakuje jednakże badań dokumentujących niepokojące zmiany w obszarze jakości bliskich związków nastolatków i młodych dorosłych, które wiązane są z częstym używaniem serwisów społecznościowych. Wiele ich rezultatów ujawnia wzrost tendencji do skupiania się na sobie lub wręcz narcystycznych zachowań 
u użytkowników tych serwisów (Ibrahim, 2009; Manago i in., 2008, Pempek, Yevdokiya, Calvert, 2009). Tendencja ta była przedmiotem badań zespołu Patricii M. Greenfield (Manago, Taylor, Greenfield, 2012). Zgodnie z przyjęta teorią zmiany społecznej (Greenfield, 2009) przewiduje się, że dobre samopoczucie oraz spostrzegane społeczne wsparcie są wynikiem przede wszystkim posiadania dużej sieci połączeń (dużej liczby znajomych) stanowiącej widownię. Analiza zmian statusów osób badanych (wkraczających w dorosłość) na Facebooku wykazała, że zachowana jest różnica pod względem rodzaju komunikowanych treści: prywatne wiadomości przekazywane są tylko osobom bliskim, publiczne zaś (pokazywanie się, ekspresja siebie) wszystkim: bliskim i dalszym znajomym. Okazało się, że dobre samopoczucie i wyższy poziom wsparcia społecznego związane były z publiczną komunikacją, natomiast nie miały związku z komunikacją prywatną. Posiadanie dużej sieci znajomych było także powodem wyższej samooceny, co autorzy wiążą z tendencjami do skupiania się na sobie. Najdalej idącym wnioskiem z powyższych badań jest przekonanie o tym, że socjalizacja poprzez serwisy społecznościowe prowadzi do przekształcania natury związków bliskich w sposób upodabniający je do publicznych, ponieważ posiadanie widowni poprawia samopoczucie i jest spostrzegane jako kapitał społeczny (Manago, Taylor, Greenfield, 2012).

Szereg obaw związanych jest z ilością czasu poświęcanego na kontakty online z przyjaciółmi oraz problematycznym używaniem internetu. Zgodnie z modelem ciągłości (między zachowaniem się w sieci internetowej i w rzeczywistości pozasieciowej) tego typu problemy są przedłużeniem trudności przeżywanych we wszystkich obszarach życia jednostki i powinny być traktowane jako ważny symptom wymagający interwencji terapeutycznej (Aboujaoude, 2010; Sampasa -Kanyinga, Lewis, 2015; Casale, Fioravanti, Rugai, 2016).

Wyniki badań w omawianym obszarze nie są jednoznaczne. Kontrowersja dotyczy przede wszystkim jakości (głębokości) relacji. Używanie serwisów społecznościowych rzeczywiście zwiększa możliwość nawiązywania i podtrzymy- wania relacji, ułatwia otwartość, zwiększa poczucie intymności i spostrzegane wsparcie społeczne. Wszystko to poprawia samopoczucie, natomiast nie jest równoznaczne z posiadaniem głębokich, wysokiej jakości relacji przyjacielskich.

\section{PROBLEM BADAWCZY I HIPOTEZY}

Wobec różnych poglądów na temat konsekwencji funkcjonowania w sieci dla bliskich relacji społecznych nastolatków i młodych dorosłych warto zbadać, czy aktywność online - przy wszystkich przedstawionych korzyściach może mieć negatywny wpływ na jakość bliskich, realnych związków. Skoro aktywność w serwisach społecznościowych skutkuje poczuciem większej bliskości i przekonaniem o dostępności wsparcia niezależnie od rodzaju relacji (znajomy, przyjaciel), możemy się spodziewać nadmiernego rozszerzania znaczenia pojęcia „przyjaciel” na osoby, z którymi jest się w częstym kontakcie dzięki komunikacji online, co jest spójne $\mathrm{z}$ wnioskami wyciągniętymi z badań zespołu Greenfield (Manago Taylor, Greenfield, 2012). Jest to bardziej prawdopodobne w grupie adolescentów, którzy mają skłonność do idealizowania związków (przypisywania korzystnych właściwości relacji bez jej sprawdzenia). W tym okresie rozwojowym potrzeba posiadania przyjaciela jest silna z uwagi na kryzysowe zjawiska związane z kształtowaniem tożsamości (Erikson, 2004), a także na zadania rozwojowe wynikające $\mathrm{z}$ rozszerzającego się środowiska społecznego i podejmowania w nim nowych, bardziej dorosłych ról. Traktowanie jako przyjaciela kogoś, kto na to miano nie zasługuje, jest w dorastaniu zjawiskiem częstym, uważanym za jedną z ważnych przyczyn negatywnego wpływu rówieśniczego (Jaccard, Blanton, Dodge, 2005; Prinstein, Wang, 2005). W związku z powyższym można się spodziewać, że w grupie adolescentów większa aktywność online będzie związana ze spostrzeganą wyższą jakością przyjaźni. Przekonanie o wysokiej jakości przyjaźni może wynikać - z jednej strony - z możliwości, jakie daje zapośredniczona komunikacja (częsty kontakt, większa otwartość, konsekwencje używania wiadomości tekstowych), z drugiej zaś - 
z nadmiernej generalizacji pojęcia przyjaźń oraz przekształcania relacji i traktowania przyjaciela jako elementu widowni. Natomiast osoby dorosłe, które realizują zadania rozwojowe wczesnej dorosłości, będą prawdopodobnie w mniejszym stopniu ulegały zjawiskom wynikającym z korzystania $\mathrm{z}$ zapośredniczonej internetem komunikacji. Można sądzić, że te osoby traktują internet jako narzędzie służące do różnych celów, bardziej dojrzała koncepcja przyjaźni zaś powoduje większy krytycyzm i wyższe oczekiwania wobec bliskiej osoby. W odniesieniu do tej grupy można się więc spodziewać braku związku między częstością kontaktów online z przyjaciółmi a spostrzeganą jakością przyjaźni. Osoby należące do grupy wkraczających w dorosłość będą prawdopodobnie podlegały tym samym prawidłowościom co grupa adolescentów z uwagi na nierozwiązany kryzys tożsamości i mniejsze - w porównaniu z dorosłymi - doświadczenia w obszarze realizowania zadań rozwojowych wczesnej dorosłości, spowodowane ich odraczaniem. Dotyczy to zwłaszcza tych zadań, które są realizowane w ramach trwałych, bliskich więzi. Należy wziąć pod uwagę, że w grupie osób wkraczających w dorosłość występuje duże zróżnicowanie pod względem zarówno zdobytych doświadczeń, jak i poziomu kompetencji społecznych. W związku z tym siła korelacji między częstością kontaktów online z przyjaciółmi a spostrzeganą jakością przyjaźni będzie $\mathrm{w}$ tej grupie przypuszczalnie słabsza niż w grupie adolescentów.

W odpowiedzi na pytanie o ewentualny wpływ kontaktów online z przyjacielem na spostrzeganą jakość przyjaźni warto wziąć pod uwagę to, że użytkownicy internetu mogą różnić się prezentowanymi wobec niego postawami. Wśród użytkowników - podobnie jak wśród badaczy tego zjawiska - znajdziemy z jednej strony optymistycznych entuzjastów nowych mediów i pełnych obaw sceptyków z drugiej. W zależności od zajmowanego miejsca na tym kontinuum internet może być wykorzystywany w obszarze relacji społecznych w różny sposób. Przykładem badań uwzględniających zróżnicowanie postaw wobec niego są ustalenia dotyczące psychospołecznych korelatów postaw wobec globalizacji (Senejko, Chmielewska-
-Łuczak, Łoś, 2015). W rezultacie przeprowadzonych badań wykryto dwie postawy wobec internetu: otwartą (OP) i przytłoczoną (PP). Pierwsza z nich charakteryzuje się otwartością na różne możliwości i funkcje oferowane przez sieć, natomiast druga łączy się z uczuciem zdominowania przez internet, utraty kontroli nad jego procesami, które przerastają użytkownika. Postawy wobec internetu mogą moderować opisane zależności między częstością kontaktów online z przyjacielem a spostrzeganą jakością przyjaźni. Postawa otwarta przypuszczalnie zwiększa siłę związku między zmiennymi, ponieważ osoby charakteryzujące się taką postawą bardziej otwarcie komunikują się online, przez co zwiększają poczucie bliskości, a także chętniej poszukują wsparcia przez internet. Natomiast w wypadku postawy przytłoczonejnawet jeśli osoba komunikuje się online i poszukuje wsparcia - to prawdopodobieństwo, że zachowania takie będą nagradzające, jest niskie (z powodu poczucia przytłoczenia). Tak więc w wypadku osób o postawie przytłoczonej częstość kontaktów online z przyjacielem nie będzie współzmienna ze spostrzeganą jakością przyjaźni lub zależność będzie miała odwrotny kierunek. W związku z powyższym postawiono następujące hipotezy badawcze:

H1: wraz ze wzrostem częstości kontaktów online z przyjacielem wzrasta spostrzegana jakość przyjacielskiego związku (w grupie adolescentów i osób wkraczających w dorosłość);

$\mathrm{H} 2$ : otwarta postawa wobec internetu moderuje ten związek, zwiększając jego siłę;

H3: postawa przytłoczona wobec internetu znosi lub zmienia kierunek tej zależności;

H4: w grupie młodych dorosłych zależność między częstością kontaktów online z przyjacielem a spostrzeganą jakością przyjaźni nie występuje.

\section{METODA}

\section{Uczestnicy}

W badaniach wzięło udział 647 osób: 291 w okresie późnej adolescencji (16-19 lat), 215 wkraczających w dorosłość (20-25 lat) oraz 141 
młodych dorosłych (26-39 lat) z Dolnego Śląska, w tym 336 kobiet i 311 mężczyzn. Dobór do badań nastolatków z okresu późnej adolescencji (uczniowie szkół średnich) był podyktowany tym, że we wcześniejszych stadiach dorastania na spostrzeganą jakość przyjaźni w większym stopniu wpływać może częstsza we wczesnym dorastaniu niestabilność przyjaźni oraz efekty związane ze zmianą szkoły (przejście z gimnazjum do szkoły średniej) niż aktywność online. O zaliczeniu do grupy osób dorosłych - poza kryterium wiekowym - decydowały dodatkowe kryteria związane $\mathrm{z}$ realizowaniem zadań wczesnej dorosłości. Grupę osób wkraczających w dorosłość tworzyli studenci różnych kierunków studiów.

\section{Techniki pomiaru}

1. Kwestionariusz Jakości Przyjaźni (KJP) autorstwa Magdaleny Żurko zawiera 20 pozycji, które tworzą 3 teoretyczne skale: (1) lubienie się i wsparcie, zawierająca 7 pozycji („Często korzystam z okazji, żeby sprawić przyjemność przyjacielowi”, „Uczymy się nawzajem od siebie radzenia sobie w pewnych sytuacjach”, „Wraz z moim przyjacielem potrafimy się nawzajem rozśmieszyć"), (2) bliskość, na którą składają się: szczerość, otwartość i wzajemne zrozumienie, łącznie 7 pozycji (np.: „Mój przyjaciel wie o mnie rzeczy, o których nikt inny nie wie”, „Mówimy sobie zarówno o pozytywnych, jak i negatywnych odczuciach względem siebie"), (3) pewność związku i zobowiązanie, zawierająca 6 pozycji (,,Wiele robię, aby na- sza przyjaźń trwała przez całe nasze życie", „Mój przyjaciel i ja nigdy nie zdradziliśmy swoich tajemnic"). Osoba badana odnosi pytania kwestionariusza do konkretnej osoby, która podaje za swojego najbliższego przyjaciela. Zastosowano czteromiejscowy format odpowiedzi. Kwestionariusz zawiera także część dotyczącą: częstości kontaktów bezpośrednich i zapośredniczonych, czasu trwania związku i okoliczności zawarcia znajomości oraz podstawowych danych dotyczących osoby badanej i jej przyjaciela. Współczynniki rzetelności zawarte są w tabeli 1. Współczynnik homogeniczności dla wszystkich skal jest zadowalający, współczynniki rzetelności dla skal: bliskość i pewność związku również, dla skali: lubienie i wsparcie jest na granicy dopuszczalności. Podskale mają charakter teoretyczny, analiza czynnikowa - analogicznie do podobnych kwestionariuszy do badania jakości przyjaźni (przegląd: Furman, 1996) - nie potwierdza wielowymiarowości konstruktu. Układ skal wynika z prawidłowości rozwojowych, to znaczy odzwierciedla rozwojowe zmiany w rozumieniu przyjaźni przez dzieci, młodzież i dorosłych. Współczynniki rzetelności dla całego kwestionariusza (traktowanego jednowymiarowo) są wysokie, a wartość współczynnika homogeniczności jest wystarczająca.

2. Kwestionariusz Internet-Relacje Interpersonalne (KIRI) autorstwa Doroty Chmielewskiej-Łuczak składa się z 29 pozycji opisujących osobiste doświadczenia związane z użytkowaniem internetu. Zastosowano

Tabela 1. Miary rzetelności: Kwestionariusz Jakości Przyjaźni (KJP)

\begin{tabular}{|l|r|r|r|r|r|r|}
\hline \multicolumn{1}{|c|}{ Skala } & Liczba pozycji & \multicolumn{1}{c|}{$\boldsymbol{\alpha}$} & \multicolumn{1}{c|}{$\boldsymbol{\lambda}-\mathbf{2}$} & \multicolumn{1}{c|}{ rho } & \multicolumn{1}{c|}{ H } & \multicolumn{1}{c|}{ av-r } \\
\hline Towarzystwo i wsparcie & 6 & .69 & .69 & .69 & .33 & .28 \\
\hline Otwartość, szczerość, zrozumienie & 7 & .72 & .72 & .72 & .31 & .27 \\
\hline Pewność związku i zobowiązanie & 7 & .76 & .76 & .75 & .35 & .31 \\
\hline Wynik ogólny & 20 & .88 & .89 & .89 & .32 & .28 \\
\hline
\end{tabular}

Nota: kolejno miary rzetelności: Alpha Cronbacha, Lambda-2 Gutmana, MS rho Molenaar Sijtsma, H Loevingera oraz średnia korelacja między pozycjami (average-r)

Źródło: opracowanie własne. 
czteromiejscowy format odpowiedzi (tak, raczej tak, raczej nie, nie). Kwestionariusz zawiera dwie skale: ustosunkowania otwartego wobec internetu (OP), zawierającą 15 pozycji („Lubię opowiadać o sobie w internecie nieznajomym ludziom") oraz ustosunkowania przytłoczonego internetem (PP), zawierającą 14 pozycji (,Męczy mnie konieczność ciagłego odpowiadania na maile znajomych"). Obie skale mają wysokie współczynniki rzetelności, odpowiednio: .85 dla OP i .80 dla PP (Senejko, Chmielewska-Łuczak, Łoś, 2015).

\section{Procedura}

Dane zostały zebrane metodami typu: papier-ołówek bez pośrednictwa internetu. Badania były anonimowe i dobrowolne, w wypadku adolescentów i osób wkraczających w dorosłość grupowe, a młodych dorosłych indywidualne. Przeprowadzono je w 2015 roku.

\section{WYNIKI}

\section{Związki w pierwszej kategorii wiekowej (16-19 lat)}

W celu weryfikacji hipotez badawczych o związku między spostrzeganiem jakości przyjaźni a częstością kontaktów zapośredniczonych in- ternetowo oraz bezpośrednich z przyjacielem przeprowadzono analizę korelacji (tabela 2). Zastosowano nieparametryczny test korelacji Tau-b Kendalla, którego właściwości sprawdzają się dobrze dla danych porządkowych i skal o małych zakresach (Brzeziński, 2001; Field, 2009).

Otrzymane współczynniki korelacji wskazują, że częstość kontaktów „twarzą w twarz” wzrasta w stopniu słabym wraz ze wzrostem nasilenia pewności związku i zobowiązania $(b=.12, p=.012)$ oraz ogólnego poziomu jakości przyjaźni $(b=.10, p=.036)$. Częstość kontaktów online z przyjacielem rośnie słabo wraz ze wzrostem pewności związku i zobowiązania ( $b=.24, p<.001)$, otwartości, szczerości i akceptacji $(b=.22, p<.001)$, towarzystwa i wsparcia $(b=.20, p<.001)$ oraz ogólnego poziomu spostrzeganej jakości przyjaźni $(b=.24, p<.001)$.

Dodatkowo obliczono statystyki rho Spearmana, ilustrujące związki między postawami wobec internetu a spostrzeganą jakością przyjaźni (tabela 3).

Współczynniki korelacji wskazują, że wraz ze wzrostem otwartość wobec internetu rośnie słabo pewność związku i zobowiązanie $(r s=.18, p=.002)$, otwartość, szczerość i akceptacja $(r s=.12, p=.040)$ oraz ogólny poziom spostrzeganej jakości przyjaźni $(r s=.15$, $p=.012$ ). Postawa przytłoczona wobec internetu nie koreluje ze spostrzeganą jakością przyjaźni.

Tabela 2. Spostrzegana jakość przyjaźni a częstość kontaktów bezpośrednich i online z przyjacielem (tau-b Kendalla, $\mathrm{N}=281$ )

\begin{tabular}{|l|c|r|}
\hline \multicolumn{1}{|c|}{ Skala } & Kontakty bezpośrednie & Kontakty online \\
\hline Towarzystwo i wsparcie & .07 & $.20^{* *}$ \\
\hline Otwartość, szczerość, zrozumienie & .08 & $.22^{* *}$ \\
\hline Pewność związku i zobowiązanie & $.12^{*}$ & $.24^{* *}$ \\
\hline Wynik ogólny & $.10^{*}$ & $.24^{* *}$ \\
\hline
\end{tabular}

$* p<.05, * * p<.01$

Źródło: opracowanie własne. 
Tabela 3. Spostrzegana jakość przyjaźni a postawy wobec internetu (rho Spearmana, N = 281)

\begin{tabular}{|l|c|r|}
\hline \multicolumn{1}{|c|}{ Skala } & Otwartość wobec internetu & Przytloczenie \\
\hline Towarzystwo i wsparcie & .07 & .06 \\
\hline Otwartość, szczerość, zrozumienie & $.12^{*}$ & .09 \\
\hline Pewność związku i zobowiązanie & $.18^{* *}$ & .10 \\
\hline Wynik ogólny & $.15^{*}$ & .10 \\
\hline
\end{tabular}

$* p<.05, * * p<.01$

Źródło: opracowanie własne.

\section{Związki w drugiej kategorii wiekowej} (20-25 lat)

Otrzymane współczynniki korelacji (tabela 4) wskazują że wzrost nasilenia częstości kontaktów „twarzą w twarz” z przyjacielem związany jest ze słabym wzrostem wyników na skali towarzystwo i wsparcie $(b=.18, p=.002)$. Umiarkowany wzrost nasilenia częstości kontaktów online z przyjacielem związany jest ze wzrostem wyników na skali towarzystwo i wsparcie $(b=$ $.31, p<.001)$, natomiast słaby wzrost nasilenia częstości kontaktów online z przyjacielem obserwujemy wraz ze wzrostem wyników na skali otwartość, szczerość i akceptacja $(b=.25$, $p<.001)$, pewność związku i zobowiązanie $(b=$ $.19, p=.001)$ i wyniku ogólnego spostrzeganej jakości przyjaźni $(b=.27, p<.001)$. W tej grupie wiekowej postawy wobec internetu nie koreluja ze spostrzeganą jakością przyjaźni (tabela 5).

Tabela 4. Spostrzegana jakość przyjaźni a częstość kontaktów bezpośrednich i online z przyjacielem (tau-b Kendalla, $\mathrm{N}=215$ )

\begin{tabular}{|l|c|r|}
\hline \multicolumn{1}{|c|}{ Skala } & Kontakty bezpośrednie & Kontakty online \\
\hline Towarzystwo i wsparcie & $.18^{*}$ & $.31^{*}$ \\
\hline Otwartość, szczerość, zrozumienie & .09 & $.25^{*}$ \\
\hline Pewność związku i zobowiązanie & .04 & $.19^{*}$ \\
\hline Wynik ogólny & .10 & $.27^{*}$ \\
\hline
\end{tabular}

$* p<.01$

Źródło: opracowanie własne.

Tabela 5. Spostrzegana jakość przyjaźni a postawy wobec internetu (rho Spearmana, $N=215$ )

\begin{tabular}{|l|r|r|}
\hline \multicolumn{1}{|c|}{ Skala } & Otwartość wobec internetu & Przytloczenie \\
\hline Towarzystwo i wsparcie & .08 & .01 \\
\hline Otwartość, szczerość, zrozumienie & .08 & .02 \\
\hline Pewność związku i zobowiązanie & .06 & .02 \\
\hline Wynik ogólny & .09 & .02 \\
\hline
\end{tabular}

Źródło: opracowanie własne. 


\section{Związki w trzeciej kategorii wiekowej (powyżej 26 lat)}

Jak wynika z tabeli 6, wzrostowi poziomu częstości kontaktów „twarzą w twarz” z przyjacielem towarzyszy słaby spadek wyników na skali otwartość, Szczerość i akceptacja $(b=-.19, p=.005)$. Częstość kontaktów online z przyjacielem nie koreluje ze spostrzeganą jakością przyjaźni.

$\mathrm{W}$ analizowanej grupie wiekowej okazało się, że otwartość wobec internetu koreluje dodatnio na poziomie umiarkowanym $\mathrm{z}$ wynikami skal: otwartość, szczerość i akceptacja ( $r s=$ $.42, p<.001)$, pewność związku i zobowiązanie $(r s=.33, p<.001)$ oraz z wynikiem ogólnym spostrzeganej jakości przyjaźni $(r s=.40, p<$ $.001)$, a na poziomie słabym także z wynikiem skali towarzystwo i wsparcie $(r s=.27, p=.001)$. Podobnie jest w przypadku postawy przytłoczonej internetem, której umiarkowany wzrost jest związany ze wzrostem wyników skal: otwartość, szczerość i akceptacja $(r s=.42, p<$ $.001)$, pewność związku i zobowiązanie $(r s=$
$.35, p<.001)$ i wyniku ogólnego spostrzeganej jakości przyjaźni $(r s=.38, p<.001)$. Postawa przytłoczona koreluje również dodatnio na poziomie słabym z wynikami skali towarzystwo i wsparcie $(r s=.20, p=.016)$ (zob. tabela 7).

\section{Wpływ częstości kontaktów online z przyjacielem na spostrzeganą jakość przyjaźni moderowany przez otwartość wobec internetu w pierwszej grupie wiekowej}

W celu zbadania, czy na podstawie częstości kontaktów online z przyjacielem oraz postawy otwartości wobec internetu można przewidywać nasilenie spostrzeganej jakości przyjaźni oraz czy postawa otwartości wobec internetu jest moderatorem relacji częstość kontaktów online z przyjacielem - spostrzegana jakość przyjaźni, przeprowadzono hierarchiczną analizę regresji (tabela 8). Każdy model poprzedzony był centracja predyktorów na podstawie metody standaryzacji.

Tabela 6. Spostrzegana jakość przyjaźni a częstość kontaktów bezpośrednich i online z przyjacielem (tau-b Kendalla, N = 141)

\begin{tabular}{|l|c|r|}
\hline \multicolumn{1}{|c|}{ Skala } & Kontakty bezpośrednie & Kontakty online \\
\hline Towarzystwo i wsparcie & -.01 & .02 \\
\hline Otwartość, szczerość, zrozumienie & $-.19 *$ & -.12 \\
\hline Pewność związku i zobowiązanie & -.09 & -.05 \\
\hline Wynik ogólny & -.11 & -.07 \\
\hline
\end{tabular}

$* p<.01$

Źródło: opracowanie własne.

Tabela 7. Spostrzegana jakość przyjaźni a postawy wobec internetu (rho Spearmana, $N=141$ )

\begin{tabular}{|l|r|r|}
\hline \multicolumn{1}{|c|}{ Skala } & Otwartość wobec internetu & \multicolumn{2}{c|}{ Przytloczenie } \\
\hline Towarzystwo i wsparcie & $.27^{* *}$ & $.20^{*}$ \\
\hline Otwartość, szczerość, zrozumienie & $.42 * *$ & $.42 * *$ \\
\hline Pewność związku i zobowiązanie & $.33^{* *}$ & $.35^{* *}$ \\
\hline Wynik ogólny & $.40^{* *}$ & $.38^{* *}$ \\
\hline
\end{tabular}

$* p<.05, * * p<.01$

Źródło: opracowanie własne. 
Tabela 8. Wpływ częstości kontaktów online z przyjacielem na spostrzeganą jakość przyjaźni moderowany przez otwartość wobec internetu w pierwszej grupie wiekowej

\begin{tabular}{|l|r|r|r|r|}
\hline \multicolumn{1}{|c|}{ Predyktor } & \multicolumn{1}{c|}{ B (SE) } & \multicolumn{1}{c|}{$\boldsymbol{\beta}$} & \multicolumn{1}{c|}{$\boldsymbol{F}$} & \multicolumn{1}{c|}{$\Delta \mathbf{R}^{\mathbf{2}}$} \\
\hline Krok 1 & & & $21.61^{* *}$ & $.133^{* *}$ \\
\hline Stała & $36.84(.47)$ & $-* *$ & & \\
\hline Częstość kontaktów online & $2.88(.49)$ & $.33^{* *}$ & & \\
\hline Otwartość & $1.59(.47)$ & $.19^{* *}$ & & \\
\hline Krok 2 & & & $14.39^{* *}$ & .000 \\
\hline Stała & $36.85(.47)$ & $-{ }^{* *}$ & & \\
\hline Częstość kontaktów online & $2.87(.49)$ & $.33^{* *}$ & & \\
\hline Otwartość & $1.61(.47)$ & $.19^{* *}$ & & \\
\hline Częstość kontaktów online* otwartość & $.14(.47)$ & .02 & & \\
\hline
\end{tabular}

Całkowite $R^{2}=.124 ; * p<.05, * * p<.01$

Źródło: opracowanie własne.

W pierwszym kroku do modelu wprowadzono częstość kontaktów online (predyktor) i wskaźnik postawy otwartości (moderator). Test Durbina-Watsona wskazał, że reszty regresji nie są skorelowane $(F=1.57)$ (nie występuje autokorelacja w modelu, a zatem błędy pomiaru są niezależne). Następnie testem współliniowości VIF (ang. variance inflation factor) $(>10)$ oraz współczynnikiem tolerancji $(<.1)$ sprawdzono skorelowanie predyktorów. Testy wykazały, że predyktory nie są ze sobą na tyle silnie związane, by siła i kierunek związku między nimi wpływały na nieprawidłowe szacowanie w modelu (nie jest więc naruszone podstawowe założenie analizy regresji) (Bedyńska, Cypryańska, 2012; Field, 2009). Zaproponowany model okazał się dobrze dopasowany do danych $[F(2,283)$ $=21.61, p<.001]$ i wyjaśniał $12,7 \%$ zmienności. Obydwie zmienne wyjaśniające okazały się istotne statystycznie: częstość kontaktów online $(\beta=.33, p<.001)$, otwartość $(\beta=.19, p=.001)$. Wzrost częstości kontaktów oraz wzrost postawy otwartości pozwala spodziewać się słabego wzrostu jakości przyjaźni. W drugim kroku do modelu wprowadzono składnik interakcyjny (częstość kontaktów online x otwartość). Otrzymany model był dobrze dopasowany do danych $[F(3,283)=14.39, p<.001]$ i wyjaśniał $12,4 \%$ wariancji, natomiast procent wyjaśnionej wa- riancji nie zmienił się znacząco $[F(1,280)=$ $.09, p=.771]$. Czynnik interakcyjny okazał się nieistotny statystycznie $(\beta=.02, p=.771)$, co oznacza, że postawa otwartości wobec internetu nie jest istotnym moderatorem.

\section{Wpływ częstości kontaktów online z przyjacielem na spostrzeganą jakość przyjaźni moderowany przez przytloczenie internetem w pierwszej grupie wiekowej}

Analogiczne analizy przeprowadzono z uwzględnieniem postawy przytłoczenia internetem.

Test Durbina-Watsona $(F=1.58)$, współczynnik współliniowości VIF ( $>10)$ oraz współczynnik tolerancji $(<0,1)$ nie wykazały, aby naruszone zostały założenia regresji. W pierwszym kroku do modelu wprowadzono częstość kontaktów online (predyktor) i wskaźnik postawy przytłoczenia (moderator). Zaproponowany model okazał się dobrze dopasowany do danych $[F(2,283)=17.77, p<.001]$ i wyjaśniał $10,6 \%$ wariancji zmiennej zależnej. Podobnie jak w poprzednim modelu wzrost wartości obydwu predyktorów pozwala przewidywać wzrost jakości przyjaźni, odpowiednio: częstość kontaktów online $(\beta=.32, p<.001)$, przytłoczenie $(\beta=.12, p=.035)$. W drugim kroku do modelu wprowadzono składnik interakcyjny (częstość 
Tabela 9. Wpływ częstości kontaktów online z przyjacielem na spostrzeganą jakość przyjaźni moderowany przez przytłoczenie internetem w pierwszej grupie wiekowej

\begin{tabular}{|l|r|r|r|r|}
\hline \multicolumn{1}{|c|}{ Predyktor } & \multicolumn{1}{c|}{ B (SE) } & \multicolumn{1}{c|}{$\boldsymbol{\beta}$} & \multicolumn{1}{c|}{$\mathbf{~}$} & \multicolumn{1}{c|}{$\Delta \mathbf{R}^{2}$} \\
\hline Krok 1 & & & $17.77^{* *}$ & $.112^{* *}$ \\
\hline Stała & $37.00(.47)$ & $-{ }^{* *}$ & & \\
\hline Częstość kontaktów online & $2.79(.50)$ & $.32^{* *}$ & & \\
\hline Przytłoczenie & $1.01(.48)$ & $.12^{*}$ & & \\
\hline Krok 2 & & & $11.91^{* *}$ & .001 \\
\hline Stała & $37.01(.47)$ & $-{ }^{* *}$ & & \\
\hline Częstość kontaktów online & $2.80(.50)$ & $.32^{* *}$ & & \\
\hline Przytłoczenie & $1.08(.49)$ & $.13^{*}$ & & \\
\hline Częstość kontaktów online* przytłoczenie & $.26(.49)$ & .03 & & \\
\hline
\end{tabular}

Całkowite $R^{2}=.104 ; * p<.05, * * p<.01$

Źródło: opracowanie własne.

kontaktów online x postawa przytłoczenia). Model regresji był dopasowany $[F(3,283)=11.91$, $p<.001]$ i wyjaśniał $10,4 \%$ wariancji. Procent wyjaśnionej wariancji nie mienił się znacząco $[F(1,280)=.28, p=.595]$. Nie wystapił efekt interakcji $(\beta=.03, p=.595)$, nie można więc uznać, aby postawa przytłoczenia internetem była istotnym moderatorem związku (tabela 9).
W analogiczny sposób obliczono efekt moderacji związku między częstotliwością kontaktów online z przyjacielem a spostrzeganą jakością przyjaźni przez postawy: otwartą i przytłoczoną wobec internetu dla pozostałych grup wiekowych (tabele 10-13). We wszystkich analizowanych przypadkach efekt moderacji nie wystąpił.

Tabela 10. Wpływ częstości kontaktów online z przyjacielem na spostrzeganą jakość przyjaźni moderowany przez otwartość wobec internetu w drugiej grupie wiekowej

\begin{tabular}{|l|r|r|r|r|}
\hline \multicolumn{1}{|c|}{ Predyktor } & \multicolumn{1}{c|}{ B (SE) } & \multicolumn{1}{c|}{$\boldsymbol{\beta}$} & \multicolumn{1}{c|}{$\mathbf{F}$} & \multicolumn{1}{c|}{$\Delta \mathbf{R}^{2}$} \\
\hline Krok 1 & & & $14.10^{* *}$ & $.117^{* *}$ \\
\hline Stała & $35.07(.54)$ & $-{ }^{* *}$ & & \\
\hline Częstość kontaktów online & $2.47(.49)$ & $.33^{* *}$ & & \\
\hline Otwartość & $1.11(.59)$ & .12 & & \\
\hline Krok 2 & & & $9.36^{* *}$ & .000 \\
\hline Stała & $35.07(.54)$ & $-{ }^{* *}$ & & \\
\hline Częstość kontaktów online & $2.46(.51)$ & $.33^{* *}$ & & \\
\hline Otwartość & $1.12(.59)$ & .12 & & \\
\hline Częstość kontaktów online* otwartość & $-.04(.54)$ & -.01 & & \\
\hline
\end{tabular}

Całkowite $R^{2}=.105 ; * p<.05, * * p<.01$

Źródło: opracowanie własne. 
Tabela 11. Wpływ częstości kontaktów online z przyjacielem na spostrzeganą jakość przyjaźni moderowany przez przytłoczenie internetem $\mathrm{w}$ drugiej grupie wiekowej

\begin{tabular}{|l|r|r|r|r|}
\hline \multicolumn{1}{|c|}{ Predyktor } & \multicolumn{1}{c|}{ B (SE) } & \multicolumn{1}{c|}{$\boldsymbol{\beta}$} & \multicolumn{1}{c|}{$\mathbf{F}$} & \multicolumn{1}{c|}{$\Delta \mathbf{R}^{\mathbf{2}}$} \\
\hline Krok 1 & & & $12.39^{* *}$ & $.105^{* *}$ \\
\hline Stała & $34.75(.51)$ & $-{ }^{* *}$ & & \\
\hline Częstość kontaktów online & $2.43(.49)$ & $.32^{* *}$ & & \\
\hline Przytłoczenie & $.39(.52)$ & .05 & & \\
\hline Krok 2 & & & $8.55^{* *}$ & .004 \\
\hline Stała & $34.76(.51)$ & $--^{* *}$ & & \\
\hline Częstość kontaktów online & $2.46(.49)$ & $.33^{* *}$ & & \\
\hline Przytłoczenie & $.30(.53)$ & .04 & & \\
\hline Częstość kontaktów online* przytłoczenie & $.41(.44)$ & .06 & & \\
\hline
\end{tabular}

Całkowite $R^{2}=.096 ;{ }^{*} p<.05, * * p<.01$

Źródło: opracowanie własne.

Tabela 12.Wpływ częstości kontaktów online z przyjacielem na spostrzeganą jakość przyjaźni moderowany przez otwartość wobec internetu w trzeciej grupie wiekowej

\begin{tabular}{|l|r|r|r|r|}
\hline \multicolumn{1}{|c|}{ Predyktor } & B (SE) & \multicolumn{1}{c|}{$\boldsymbol{\beta}$} & \multicolumn{1}{c|}{$\mathbf{F}$} & \multicolumn{1}{c|}{$\Delta \mathbf{R}^{\mathbf{2}}$} \\
\hline Krok 1 & & & $10.91^{* *}$ & $.137^{* *}$ \\
\hline Stała & $39.78(.74)$ & $-{ }^{* *}$ & & \\
\hline Częstość kontaktów online & $.35(.71)$ & .04 & & \\
\hline Otwartość & $2.94(.65)$ & $.38^{* *}$ & & \\
\hline Krok 2 & & & $7.45^{* *}$ & .004 \\
\hline Stała & $39.59(.78)$ & $-{ }^{* *}$ & & \\
\hline Częstość kontaktów online & $.38(.71)$ & .05 & & \\
\hline Otwartość & $3.10(.68)$ & $.40^{* *}$ & & \\
\hline Częstość kontaktów online* otwartość & $-.46(.60)$ & -.06 & & \\
\hline
\end{tabular}

Całkowite $R^{2}=.121 ; * p<.05, * * p<.01$

Źródło: opracowanie własne.

Tabela 13. Wpływ częstości kontaktów online z przyjacielem na spostrzeganą jakość przyjaźni moderowany przez przytłoczenie internetem $w$ trzeciej grupie wiekowej

\begin{tabular}{|l|r|r|r|r|}
\hline \multicolumn{1}{|c|}{ Predyktor } & B (SE) & $\boldsymbol{\beta}$ & \multicolumn{1}{c|}{$\mathbf{F}$} & \multicolumn{1}{c|}{$\Delta \mathbf{R}^{\mathbf{2}}$} \\
\hline Krok 1 & & & $11.50^{* *}$ & $.143^{* *}$ \\
\hline Stała & $39.95(.72)$ & $-* *$ & & \\
\hline Częstość kontaktów online & $-.05(.68)$ & -.01 & & \\
\hline Przytłoczenie & $3.08(.66)$ & $.38^{* *}$ & & \\
\hline Krok 2 & & & $7.74^{* *}$ & .002 \\
\hline Stała & $39.85(.75)$ & $-{ }^{* *}$ & & \\
\hline Częstość kontaktów online & $.02(.69)$ & .00 & & \\
\hline Przytłoczenie & $3.18(.69)$ & $.39^{* *}$ & & \\
\hline Częstość kontaktów online* przytłoczenie & $-.35(.62)$ & -.05 & & \\
\hline
\end{tabular}

Całkowite $R^{2}=.126 ; * p<.05, * * p<.01$

Źródło: opracowanie własne. 


\section{DYSKUSJA}

W odpowiedzi na pytanie o związki między częstością kontaktów online z przyjacielem a spostrzeganą jakością przyjaźni ustalono, że przewidywana dodatnia zależność występuje w grupie adolescentów oraz osób wkraczających w dorosłość, lecz jest to zależność słaba. Potwierdził się przewidywany brak takiej zależności w grupie młodych dorosłych (osoby powyżej 26 lat). Analiza wyników na poszczególnych podskalach wykazała, że najsilniejszy (umiarkowany) związek dotyczy wzrostu wyników na skali: towarzystwo i wsparcie wraz ze wzrostem częstości kontaktów online z przyjacielem $\mathrm{w}$ grupie osób wkraczających $\mathrm{w}$ dorosłość. Odwołując się do ustaleń dotyczących zmniejszenia ilości czasu spędzanego z przyjaciółmi w okresie wkraczania w dorosłość w porównaniu $z$ adolescencją (Tanner, Arnett, 2011), można sądzić, że kontakty online z przyjacielem są wygodną dla osób w tym okresie rozwojowym formą podtrzymywania ukształtowanych, bliskich więzi. Wyniki uzyskane w grupie adolescentów i osób wkraczających w dorosłość nie potwierdzają obaw o to, że częste kontakty online z przyjacielem wiążą się ze spłyceniem przyjacielskich związków (Manago, Taylor, Greenfield, 2012). Należy jednak mieć na uwadze, że badano spostrzeganą, a nie obiektywną jakość przyjaźni. Uzyskane zależności między częstością używania internetu do kontaktowania się z przyjacielem a spostrzeganą jakością związku w grupie adolescentów i osób wkraczających w dorosłość mogą być także efektem łatwego w tym wieku uznawania kogoś, z kim jest się w częstym, miłym kontakcie, za przyjaciela. Konsekwencje korzystania z serwisów społecznościowych, takie jak: dobre samopoczucie, przekonanie o tym, że osoba, z którą często wymienia się komunikaty, jest gotowa pomóc w trudnej sytuacji, poczucie autentycznej bliskości na podstawie otwartości w wymianie informacji, a przede wszystkim dzielenie przeżyć i poglądów charakteryzują związki młodzieńcze. $Z$ tego względu kluczowe jest przeanalizowanie związków z podskalą pewność i zobowiązanie jako najpóźniejszego rozwojowo składnika jakości przyjaźni. O ile w grupie adolescentów siła korelacji dla poszczególnych skal jest podobna (słaba), o tyle w grupie osób wkraczających w dorosłość najsłabsza jest właśnie dla podskali pewność i zobowiązanie, relatywnie najsilniejsza zaś (umiarkowana) dla podskali towarzystwo i wsparcie stanowiącej najwcześniejszy rozwojowo składnik jakości przyjaźni. Tak więc osoby wkraczające w dorosłość podlegają opisanym wcześniej mechanizmom związanym z aktywnością w serwisach społecznościowych, ale dotyczy to przede wszystkim przekonania o dostępności wsparcia i poprawienia nastroju związanego z kontaktem z przyjacielem, natomiast $\mathrm{w}$ mniejszym stopniu dotyczy tych składników jakości przyjaźni, które nie mają obiektywnego związku z używaniem internetu (pewność i zobowiązanie). Stabilność przyjaźni wynikająca z wzajemnego zobowiązania jest wszakże uwarunkowana stabilnością wewnętrzną partnerów opartą na ukształtowanej, dojrzałej tożsamości (Erikson, 2004). Dojrzała przyjaźń - poza tym, że jest sprawdzona ukierunkowana jest na wspólne realizowanie wartości wykraczających poza przyjemność płynącą z kontaktu i wspólnoty przeżyć, a także poza jej użyteczność (wsparcie). Na podstawie wyników dotyczących osób dorosłych można sądzić, że ukształtowana, dojrzała koncepcja przyjaźni sprzyja dystansowaniu się wobec specyfiki narzędzia używanego do komunikowania się. Należy wziąć także pod uwagę, że osoby dorosłe biorące udział w tym badaniu miały możliwość korzystania z Facebooka najwcześniej od dziewiętnastego roku życia*, więc brak efektu współzmienności może być wywołany późniejszym czasem oddziaływań, kiedy podatność na nie jest mniejsza. Wyniki korelacji między postawą wobec internetu a spostrzeganą jakością przyjaźni wskazują, że zależność między postawą otwartą a spostrzeganą jakością przyjaźni występuje w grupie adolescentów i jest słaba oraz młodych dorosłych i jest umiarkowana. Można więc sądzić, że postawa otwartości jest generalizowana także na bliskie relacje, zwiększając tym samym poczucie bliskości i jakości związku.

* Polska wersja językowa Facebooka funkcjonuje od 2008 roku. 
Przeprowadzone analizy nie dają jednak podstaw do uznania postaw wobec internetu jako moderatora związku między częstością kontaktów online a spostrzeganą jakością przyjaźni (nie wystapił efekt interakcyjny). Uzyskany związek między postawą przytłoczenia internetem a spostrzegana jakością przyjaźni w grupie młodych dorosłych jest odwrotny od przewidywanego: im większe jest poczucie przytłoczenia internetem, tym wyższa jest spostrzegana jakość przyjaźni. Niewykluczone, że osoby dorosłe nielubiące sieci preferują kontakty z przyjaciółmi „twarzą w twarz", co wiąże się z większym wysiłkiem wkładanym w pielęgnowanie związku, zwłaszcza że wczesna dorosłość jest okresem zaangażowania w szereg nowych, obciążających zadań. Intensywniejsze starania mogą wiązać się ze spostrzeganą wyższą jakością przyjaźni. Należy jednak mieć na uwadze, że badana grupa osób dorosłych jest mało liczna (141 osób), a próba nielosowa. Zmienne w postaci postaw mają charakter ogólny i przy zastosowaniu procedury korelacyjnej współzmienność czasami występuje, a czasami zanika, co jest zależne od kolejnych, potencjalnych moderatorów. Kwestia ta wymaga dalszych badań.

\section{OGRANICZENIA I PERSPEKTYWY BADAWCZE}

Ograniczenia dotyczące wniosków wynikają ze specyfiki zastosowanej metody, która dostarcza danych samoopisowych. Ponadto w badaniu nie porównywano wyników w przyjacielskiej diadzie, co nie pozwoliło na ustalenie jednego z ważniejszych wskaźników jakości związku, jakim jest wzajemność (na temat trudności w badaniach par przyjaciół: Bukowski, Motzoi, Meyer, 2009). Tak więc wyniki dotyczą wyobrażeń i poglądów osób badanych na temat ich przyjacielskich związków, a nie ich obiektywnej jakości. Badanie subiektywnych przekonań na temat jakości przyjacielskiej relacji jest uzasadnione tym, że regulują one wiele zjawisk i procesów psychicznych, zwłaszcza w okresie dorastania (podatność na wpływ rówieśniczy, poczucie własnej wartości i dostępności wsparcia, adaptacja szkolna, pozycja w grupie $\mathrm{i}$ inne).

Podskale w kwestionariuszu KJP mają charakter teoretyczny, w związku z czym bardziej pewne są wnioski wyciągane z wyników ogólnych kwestionariusza. Należy także wziąć pod uwagę, że dobór osób badanych nie był losowy, a uzyskane korelacje okazywały się słabe lub umiarkowane.

Rezultaty badań nad konsekwencjami korzystania z usług internetowych dotyczą zjawisk o dużej dynamice. Obecnie nastolatki są onlinedzięki posiadanym smartfonom - praktycznie bez przerwy, zwiększa się oferta internetowa (np. granie $\mathrm{z}$ przyjacielem za pośrednictwem sieci jest także formą kontaktu z dodatkową specyfiką wynikającą z samego grania), niektóre usługi i aplikacje nie zdobywają popularności, inne przeciwnie: stają się zalążkiem nowych przedsiębiorstw informatycznych. Różnorodność, zmienność i zwiększająca się popularność internetowych usług szybko dezaktualizuje ustalenia badawcze w tym obszarze, dlatego warto je powtarzać i modyfikować zależnie od dynamiki wirtualnego świata.

Wartościowym uzupełnieniem badań nad przyjaźnią mogą być rezultaty uzyskane z zastosowaniem metod jakościowych ze względu na wagę głębszych aspektów przyjaźni w ocenie jej jakości (Żurko, 2011).

\section{PODZIĘKOWANIA}

Artykuł powstał na podstawie danych uzyskanych w ramach badań statutowych nr 37 Instytutu Psychologii Uniwersytetu Wrocławskiego kierowanych przez dr hab. Alicję Senejko, a dotyczących psychologicznych aspektów globalizacji. Dziękuję wszystkim współpracownikom, dzięki którym powstała baza danych zawierająca wyniki wykorzystane w artykule. 


\section{BIBLIOGRAFIA}

Aboujaoude E. (2010), Problematic Internet Use: An Overview. World Psychiatry, 9, 2, 85-90.

Bagwell C.L., Bender S.E., Andreassi C.L., Kinoshita T.L., Montarello S.A., Muller J.G. (2005), Friendship Quality and Perceived Relationship Changes Predict Psychosocial Adjustment in Early Adulthood. Journal of Social and Personal Relationships, 22, 235-254.

Barani K. (2009), Rola więzi online w życiu społecznym człowieka. W: B. Szmigielska (red.), Psychologiczne konteksty Internetu, 103-118. Kraków: WAM.

Bargh J.A., McKenna K.Y.A. (2004), The Internet and Social Life. Annual Review of Psychology, 55, 573-590.

Batorski D. (2004), Ku społeczeństwu informacyjnemu. W: J. Czapiński, T. Panek (red.), Diagnoza Społeczna 2003: Warunki i jakość życia Polaków, 195-235. Warszawa: Wyższa Szkoła Finansów i Zarządzania.

Batorski D. (2005), Internet a usieciowienie relacji społecznych. Kultura Wspótczesna, 1, 43, 41-62.

Bedyńska S., Cypryańska M. (2012), Statystyczny drogowskaz 1. Praktyczne wprowadzenie do wnioskowania statystycznego. Warszawa: Wydawnictwo Akademickie Sedno SWPS.

Bessiere K., Kiesler S., Kraut R., Boneva B. (2008), Effects of Internet Use and Social Resources on Changes in Depression. Information, Communication, and Society, 11, 47-70.

Berndt T.J. (2002), Friendship Quality and Social Development. Current Directions in Psychological Science, 11, 7-10.

Bee H., Boyd D. (2008), Psychologia rozwoju człowieka, tłum. J. Gilewicz, A. Wojciechowski. Poznań: Wydawnictwo Zysk i S-ka.

Brzeziński J. (2000), Badania eksperymentalne w psychologii i pedagogice. Warszawa: Wydawnictwo Naukowe „Scholar”.

Buhrmester D. (1990), Intimacy of Friendship, Interpersonal Competence and Adjustment during Preadolescence and Adolescence. Child Development, 61, 1101-1111.

Bukowski W.M., Hoza B., Boivin M. (1994), Measuring Friendship Quality during Pre-and Early Adolescence: The Development and Psychometric Properties of the Friendship Qualities Scale. Journal of Social and Personal Relationships, 11, 471-484.

Bukowski W.M., Motzoi C., Meyer F. (2009), Friendship as Process, Function and Outcome. W: K.H. Rubin, W.M. Bukowski, B. Laursen (eds.), Handbook of Peer Interaction, Relationships and Groups, 217-228. New York: Guilford Press.

Carbery J., Buhrmester D. (1998), Friendship and Need Fulfillment during Three Phases of Young Adulthood. Journal of Social and Personal Relationships, 15, 393-409.

Casale S., Fioravanti G., Rugai L. (2016), Grandiose and Vulnerable Narcissists: Who Is at Higher Risk for Social Networking Addiction? Cyberpsychology, Behavior, and Social Networking, 19, 8, 510-515. DOI:10.1089/cyber.2016.0189.

Castells M. (2007), Społeczeństwo sieci, thum. M. Maroda i in. Warszawa: Wydawnictwo Naukowe PWN.

Daddis Ch. (2008), Similarity between Early and Middle Adolescent Close Friends' Beliefs about Personal Jurisdiction. Social Developement, 17, 4, 1019-1038.

Dunn J. (2008), Przyjaźnie dzieci, thum. Am Białecka-Pikul. Kraków: Wydawnictwo Uniwersytetu Jagiellońskiego.

Ellison N.B., Steinfield C., Lampe C. (2007), The Benefits of Facebook 'Friends': Exploring the Relationship between College Students' Use of Online Social Networks and Social Capital. Journal of Computermediated Communication, 12, 1143-1168.

Erikson H.E. (2004), Tożsamość a cykl życia, tłum. M. Żywicki. Poznań: Wydawnictwo Zysk i S-ka.

Field A. (2009), Discovering Statistic Using SPSS. London: Sage Publications Ltd.

Furman W. (1996), The Measurement of Friendship Perceptions: Conceptual and Methodological Issues. W: W.M. Bukowski, A.F. Newcomb, W.W. Hartup (eds.), The Company They Keep: Friendship in Childhoodand Adolescence, 41- 65, Cambridge: Cambridge University Press.

Furman W. (2001), Working Models of Friendships. Journal of Social \& Personal Relationships, 18, 5, 583602. DOI: $10.1177 / 0265407501185002$.

Gauze C., Bukowski W.M., Aquan-Assee J., Sippola L.K. (1996), Interaction between Family Environment and Friendship and Associations with Self-Perceived Well-Being during Early Adolescence. Child Development, 67, 5, 2201-2216. 
Greenfield P.M. (2009), Linking social change and developmental change: Shifting pathways of human development. Developmental Psychology, 45, 401-418. DOI:10.1037/a0014726.

Hartup W.W. (1993), Adolescents and their friends. W: B. Laursen (ed.), Close Friendships in Adolescence, 3-22. San Francisco, CA: Jossey-Bass.

Heilbron N., Prinstein M.J. (2008), Peer Influence and Adolescent Nonsuicidal Self-Injury: A Theoretical Review of Mechanisms and Moderators. Applied and Preventive Psychology, 12, 169-177.

Hinde R.A. (1996), Describing Relationships. W: A.E. Auhagen, M. von Salisch (eds.), The Diversity of Human Relationships, 7-35. Cambridge: Cambridge University Press.

Ibrahim Y. (2009), Social Networking Sites (SNS) and the "Narcissisticturn". The Politics of Self-Exposure. W: S. Rummler, K.B. Ng (eds.), Collaborative Technologies and Applications for Interactive Information Design: Emerging Trends in User Experiences, 82-95. Hershey, PA: Idea Group.

Jaccard J., Blanton H., Dodge T. (2005), Peer Influences on Risk Behavior: An Analysis of the Effect of a Close Friend. Developmental Psychology, 43, 1, s. 135-147.

Kraut R., Patterson M., Lundmark V., Kiesler S., Mukhopadhyay T., Scherlis W. (1998), Internet Paradox: A Social Technology That Reduces Social Involvement and Psychological Well-Being? American Psychologist, 53, 1017-1031.

Krejtz K., Zając J.M. (2007), Internet jako przedmiot i obszar badań psychologii społecznej. Psychologia Spoteczna, 2, 3-4, 191-200.

Lozano E.B., Hojjat M., Sims-Knight J. (2016), Does Ego-Resilience Impact Friendship Outcomes? Journal of Individual Differences, 37, 2, 128-134.

Manago A.M., Graham M., Greenfield P.M., Salimkhan G. (2008), Self-Presentation and Gender on MySpace. Journal of Applied Developmental Psychology, 29, 446-458.

Manago A.M., Taylor T., Greenfield P.M. (2012), Me and My 400 Friends: The Anatomy of College Students' Facebook Networks, Their Communication Patterns, and Well-Being. Developmental Psychology, 48, 2, 369-380.

Mendelson M.J., Aboud F. (1999), Measuring Friendship Quality in Late Adolescents and Young Adults: McGill Friendship Questionnaires. Canadian Journal of Behavioural Science, 31, 130-132.

Mikami A.Y., Szwedo D.E., Allen J.P., Evans M.A., Hare A.L. (2010), Adolescent Peer Relationships and Behavior Problems Predict Young Adults' Communication on Social Networking Websites. Developmental Psychology, 46, 46-56.

Parks R.M., Floyd K. (1996), Making Friends in Cyberspace. Journal of Computer-Mediated Communication, 1, 4, 0-0. DOI: 10.1111/j.1083-6101.1996.tb00176.x.

Pempek T.A., Yevdokiya A.Y., Calvert S.L. (2009), College Students' Social Networking Experiences on Facebook. Journal of Applied Developmental Psychology, 30, 227-238.

Prinstein M.J., Wang S.S. (2005), False Consensus and Adolescent Peer Contagion: Examining Discrepancies between Perceptions and Actual Reported Levels of Friends' Deviant and Health Risk Behaviors. Journal of Abnormal Child Psychology, 33, 3, 293-306.

Pulakos J. (2001), Young Adult Relationships: Siblings and Friends. Journal of Psychology, 123, 237-244.

Rabaglietti E., Ciaviano S. (2008), Quality of Friendship Relationship and Development Tasks in Adolescence. Cognition, Brain, Behavior, 12, 2, 183-203.

Rheingold H. (1993), The Virtual Community: Homesteading on the Electronic Frontier. Boston: Addison-Wesley.

Rubin K.H., Bukowski W., Parker J.G. (1998), Peer Interactions, Relationships, and Groups. W: W. Damon, N. Eisenberg (eds.), Handbook of Child Psychology, vol. 3: Social, Emotional, and Personality Development, 619-700. New York: Wiley.

Sampasa-Kanyinga H., Lewis R.F. (2015), Frequent Use of Social Networking Sites Is Associated with Poor Psychological Functioning among Children and Adolescents. Cyberpsychology, Behavior, and Social Networking, 18, 7, 380-385. DOI:10.1089/cyber.2015.0055.

Senejko A., Chmielewska-Łuczak D., Łoś Z. (2015), Internet Usage Styles and Attitudes toward Globalization. Polish Journal of Applied Psychology, 13, 1, 9-32.

Sheer V.C. (2011), Teenagers' Use of MSN Features, Discussion Topics, and Online Friendship Development: The Impact of Media Richness and Communication Control. Communication Quarterly, 59, 1, 82-103. 
Subrahmanyam K., Reich S.M., Waechter N., Espinoza G. (2008), Online and Offline Social Networks: Use of Social Networking Sites by Emerging Adults. Journal of Applied Developmental Psychology, 29, 420-433.

Szmigielska B. (red.) (2008), Całe życie w sieci. Kraków: Wydawnictwo Uniwersytetu Jagiellońskiego.

Szmigielska B. (red.) (2009), Psychologiczne konteksty internetu. Kraków: WAM.

Szwedo D.E., Mikami A.Y., Allen J.P. (2012), Social Networking Site Use Predicts Changes in Young Adults'Psychological Adjustment. Journal of Research on Adolescence, 22(3), 453-466. DOI: 10.1111/j.15327795.2012.00788.x.

Tanner J.L., Arnett J.J. (2011), Presenting „Emerging Adulthood”: What Makes it Developmentally Distinctive? W: J.J. Arnett, M. Kloep, L.B. Hendry, J.L. Tanner (eds.), Debating Emerging Adulthood. Stage or Process?, 13-30. New York: Oxford University Press.

Urberg K.A., Luo Q., Pilgrim C., Degirmencioglu S.M. (2003), A Two-stage Model of Peer Influence in Adolescent Substance Use: Individual and Relationship - Specific Differences in Susceptibility to Influence. Addictive Behaviors, 28, 1243-1256.

Valkenburg P.M., Peter J. (2007), Preadolescents' and Adolescents' Online Communication and Their Closeness to Friends. Developmental Psychology, 43, 2, 267-277.

Valkenburg P.M., Peter J. (2009), Social Consequences of the Internet for Adolescents a Decade of Research. Current Directions in Psychological Science, 18, 1, 1-5.

Van Dijk J. (2010), Społeczne aspekty nowych mediów, tłum. J. Konieczny. Warszawa: Wydawnictwo Naukowe PWN.

Wang H., Wellman B. (2010), Social Connectivity in America: Changes Inadult Friendship Network Size from 2002 to 2007. American Behavioral Scientist, 53, 8, 1148-1169.

Webster A.A., Carter M. (2013), A Descriptive Examination of the Types of Relationships Formed between Children with Developmental Disability and Their Closest Peers in Inclusive School Settings. Journal of Intellectual \& Developmental Disability, 38, 1, 1-11.

Wojciszke B. (1998), Psychologia miłości. Namiętność, intymność, zaangażowanie. Gdańsk: Gdańskie Wydawnictwo Psychologiczne.

Yu Rueger S., Malecki Ch., Demaray M.K. (2008), Gender Differences in the Relationship between Perceived Social Support and Student Adjustment during Early Adolescence. School Psychology Quarterly, 23, 4, 496-514. DOI: 10.1037/1045-3830.23.4.496.

Żurko M. (2011), Friendship during Adolescence: The Necessity for Qualitative Research of Close Relationships. Polish Journal of Applied Psychology, 9, 21-38. 


\section{KWESTIONARIUSZ JAKOŚCI PRZYJAŹNI (KJP)}

opracowanie Magdalena Żurko

1. Mój przyjaciel wie o mnie rzeczy, o których nikt inny nie wie.

2. Przy moim przyjacielu nie muszę udawać kogoś, kim nie jestem.

3. Uczymy się nawzajem od siebie radzenia sobie w pewnych sytuacjach.

4. Wraz z moim przyjacielem potrafimy się nawzajem rozśmieszyć.

5. Wszyscy wiedzą, że jesteśmy przyjaciółmi.

6. Mój przyjaciel zawsze ma czas, żeby mnie wysłuchać.

7. Wolę nie mówić o wszystkim w obecności mojego przyjaciela.

8. Wiele robię, aby nasza przyjaźń trwała przez całe nasze życie.

9. Mówimy sobie zarówno o pozytywnych, jak i negatywnych odczuciach względem siebie.

10. Mój przyjaciel i ja nigdy nie zdradziliśmy swoich tajemnic.

11. Sądzę, że przyjdzie czas, kiedy rozstaniemy się z przyjacielem.

12. Mój przyjaciel często używa moich rzeczy, a ja używam jego.

13. Mój przyjaciel zawsze dotrzymuje danego mi słowa.

14. Interesują mnie przeżycia, uczucia i opinie mojego przyjaciela, a jego interesują moje.

15. Znam sytuację rodzinną mojego przyjaciela, a on zna moją.

16. Często nie wiem, o co chodzi mojemu przyjacielowi.

17. Często korzystam z okazji, żeby sprawić przyjemność przyjacielowi.

18. Tak organizuję swój czas, abym mógł regularnie odwiedzać swojego przyjaciela.

19. Miałem okazję przekonać się, że mogę liczyć na mojego przyjaciela.

20. Z moim przyjacielem rozumiemy się bez słów.

Źródło: opracowanie własne. 


\title{
Kwestionariusz Internet-Relacje Interpersonalne (KIRI)
}

\author{
(Internet-Interpersonal Relations Questionnaire)
}

opracowanie: Dorota Chmielewska-Łuczak

KOD OSOBY BADANEJ

PŁEĆ.

WIEK

MIEJSCE ZAMIESZKANIA (podkreśl właściwą odpowiedź): WIEŚ, MIASTECZKO, MIASTO, MIASTO WOJEWÓDZKIE

Kwestionariusz zawiera szereg twierdzeń opisujących Twoje spostrzeżenia i odczucia na temat komunikacji i zdarzeń występujących w internecie. Pytania od 1 do 6 mają charakter pytań wprowadzających - odpowiadaj na nie zgodnie z instrukcją umieszczoną przy danym pytaniu.

Zaczynając od twierdzenia 7, stosuj się do poniższej instrukcji:

Jeśli z danym twierdzeniem zgadzasz się całkowicie, jeśli jest ono prawdziwe w odniesieniu do Ciebie - zaznacz obok odpowiedź „Tak” (T), a jeśli zgadzasz się częściowo - zaznacz odpowiedź „raczej tak” (rt).

Jeśli z tym twierdzeniem nie zgadzasz się wcale lub w ogóle nie charakteryzuje ono Ciebie zaznacz odpowiedź „Nie” (N), a jeśli raczej nie zgadzasz się lub twierdzenie charakteryzuje Ciebie tylko w niewielkim stopniu - zaznacz „raczej nie” (rn). Zaznaczaj swoje odpowiedzi przez otoczenie właściwych liter kółkiem.

Nie pomijaj żadnego twierdzenia. Nie ma tu dobrych czy złych odpowiedzi, każda - jeśli opisuje Twoje stanowisko lub odczucia - jest prawidłowa. 


\begin{tabular}{|c|c|}
\hline 1. Czy korzystasz z internetu? (zaznacz właściwą odpowiedź) & TAK NIE \\
\hline $\begin{array}{l}\text { 2. Od jak dawna jesteś użytkownikiem Internetu? (zaznacz jedną właściwą od- } \\
\text { powiedź) } \\
\text { a. poniżej } 6 \text { miesięcy, } \\
\text { b. od } 6 \text { miesięcy do } 1 \text { roku, } \\
\text { c. } 1-3 \text { lata, } \\
\text { d. } 3-5 \text { lat, } \\
\text { e. powyżej } 5 \text { lat. }\end{array}$ & a.b.c.d.e. \\
\hline $\begin{array}{l}\text { 3. Jak często używasz internetu? (zaznacz jedną właściwą odpowiedź) } \\
\text { a. kilka razy dziennie, } \\
\text { b. raz dziennie, } \\
\text { c. co kilka dni, } \\
\text { d. raz w tygodniu, } \\
\text { e. rzadziej niż raz w tygodniu. }\end{array}$ & a.b.c.d.e. \\
\hline $\begin{array}{l}\text { 4. Na jak długo wchodzisz do internetu (zaznacz jedną właściwą odpowiedź) } \\
\text { a. mniej niż godzinę, } \\
\text { b. } 2-3 \text { godziny, } \\
\text { c. powyżej } 3 \text { godzin. }\end{array}$ & a.b.c. \\
\hline $\begin{array}{l}\text { 5. Czy internetu używasz przede wszystkim do: (zaznacz właściwe odpowiedzi - } \\
\text { możesz wybrać kilka) } \\
\text { a. pracy, } \\
\text { b. w czasie wolnym (rozrywka, hobby) } \\
\text { c. działań charytatywnych, } \\
\text { d. działania na rzecz organizacji, } \\
\text { e. relacji z ludźmi. }\end{array}$ & a.b.c.d.e. \\
\hline $\begin{array}{l}\text { 6. W jakim celu kontaktujesz się z ludźmi poprzez internet (zaznacz właściwe } \\
\text { odpowiedzi - możesz wybrać kilka) } \\
\text { a. w sprawach zawodowych, } \\
\text { b. kontaktuję się z ludźmi, którzy podzielają moje zainteresowania, } \\
\text { c. poznaję nieznajomych ludzi, } \\
\text { d. szukam partnera, } \\
\text { e. szukam przyjaciół, } \\
\text { d. jestem w kontakcie z bliskimi, } \\
\text { e. podtrzymuję kontakt z osobami, których nie mogę widzieć osobiście. }\end{array}$ & a.b.c.d.e. \\
\hline
\end{tabular}

\begin{tabular}{|c|c|}
\hline 7. Lubię wypowiadać się na forach internetowych. & Trt rn N \\
\hline $\begin{array}{l}\text { 8. W internecie spotkałem „,bratnie dusze”, z którymi dzielę się swoimi przemy- } \\
\text { śleniami i emocjami. }\end{array}$ & Trt rn N \\
\hline 9. Jestem przytłoczony tym, jak wiele informacji jest do mnie przesyłanych w sieci. & Trt rn N \\
\hline 10. Lubię poważne rozmowy przez internet. & Trt rn N \\
\hline $\begin{array}{l}\text { 11. Wpadam w złość, gdy jestem w internecie i rozmawiam z ludźmi lub czytam } \\
\text { to, co napisali. }\end{array}$ & T rt rn N \\
\hline 12. Lubię opowiadać o sobie w internecie nieznajomym ludziom. & Trt rn N \\
\hline 13. Mam dużo przemyśleń na swój temat, gdy jestem w internecie. & Trt rn N \\
\hline $\begin{array}{l}\text { 14. Mam więcej znajomych, z którymi utrzymuję kontakt poprzez internet niż } \\
\text { w inny sposób (telefon, tradycyjna korespondencja, kontakt „twarzą w twarz”). }\end{array}$ & T rt rn N \\
\hline 15. Jestem bombardowany nieustannie informacjami z sieci. & Trt rn N \\
\hline 16. Rozmawiam o intymnych sprawach w internecie. & Trt rn N \\
\hline 17. Wolę kontaktować się z ludźmi online. & $\mathrm{T} \operatorname{rtrn} \mathrm{N}$ \\
\hline 18. Odcinam się od znajomych z sieci, którzy przesyłają mi za dużo różnych rzeczy. & Trt rn N \\
\hline
\end{tabular}




\begin{tabular}{|c|c|}
\hline $\begin{array}{l}\text { 19. W komunikacji z innymi online są nieporozumienia, które nie wiem, skąd się } \\
\text { biorą. }\end{array}$ & T rt rn N \\
\hline $\begin{array}{l}\text { 20. Gdy nie wiem, co sobie myślą o mnie znajomi, którzy czytają to, co napisałem } \\
\text { w sieci, wyobrażam sobie najgorsze. }\end{array}$ & Trt rn N \\
\hline 21. Męczy mnie konieczność ciągłego odpowiadania na maile znajomych. & Trt rn N \\
\hline $\begin{array}{l}\text { 22. Lubię rozmawiać z nieznajomymi w internecie, ale nie zależy mi na poznawa- } \\
\text { niu ich w realnym świecie. }\end{array}$ & T rt rn N \\
\hline 23. Mniej się denerwuję, gdy jestem w kontakcie z innymi poprzez internet. & Trt rn N \\
\hline 24. Zwierzam się częściej ludziom w internecie z rzeczy, których nie mówię nikomu. & Trt rn N \\
\hline 25. Nie nadążam z czytaniem ciągle nowych informacji z sieci. & Trt rn N \\
\hline 26. Ludzie mnie denerwują w internecie. & Trt rn N \\
\hline $\begin{array}{l}\text { 27. Denerwuje mnie to, że nie rozumiem, co osoba, z którą się kontaktuję online, } \\
\text { ma na myśli. }\end{array}$ & Trt rn N \\
\hline 28. Czuję się swobodniej, komunikując się przez internet. & Trt rn N \\
\hline 29. Denerwuje mnie to, że ciagle dostaję nowe oferty z sieci. & Trt rn N \\
\hline 30. Ludzie w internecie nie wyrażają się w sposób jasny. & T rt rn N \\
\hline $\begin{array}{l}\text { 31. Lubię czytać swoje wypowiedzi na forach internetowych, blogach, komenta- } \\
\text { rzach, mailach. }\end{array}$ & Trt rn N \\
\hline 32. Uważam, że w sieci jest wszystkiego za dużo. & Trt rn N \\
\hline 33. Mogę znacznie więcej opowiedzieć o sobie w internecie. & Trt rn N \\
\hline 34. Odkąd używam internetu, mam więcej dobrych przyjaciół. & T rt rn N \\
\hline 35. Denerwuję się, gdy wysyłam maila i nie wiem, jak będzie odebrany. & T rt rn N \\
\hline
\end{tabular}

